\title{
Observations and results of pathogenic bacteria from untreated freshwater sources
}

\author{
Iuliana Beleuzu Boda, Marius Cristian Boda
}

\author{
University of Agronomic Sciences and Veterinary Medicine of Bucharest, \\ Biotechnology Faculty, Romania
}

Keywords:

Water

Microbiology

Drinking

Microorganisms

Escherichia coli

Pseudomonas

aeruginosa

Article history:

Received 01.10.2016

Received in revised

form 07.12.2016

Accepted 30.12.2016

Corresponding author:

Marius Cristian Boda

E-mail:

mariusboda@yahoo.com

DOI: $10.24263 / 2310-$

1008-2016-4-2-10

\section{Abstract}

Introduction. Insufficient drinking water sources, quality and in some cases reduced cleanness are between the humanity key reasons of inevitable illness and mortality causing between two million to four million deceases per year.

Materials and methods. The investigation results were obtained using membrane filtration method running water samples across two counties in UK last year. The rest of the sources provided are from lakes, reservoirs and rivers. The culture media plates were prepared in house or bought ready to be used for Pseudomonas aeruginosa, Escherichia Coli and Coliform Sp.

Results and discussion. Findings of microorganisms in the freshwater sources were not surprising as almost all the sources can be contaminated through natural processes, although positive results for pathogen organisms were found on the locations where the contamination was more like to happen, like busy River canals or near animals grazing areas.

The study results establish Pseudomonas and other microorganisms' contamination, through the membrane filtration method, in several samples taken from freshwater sources. In addition, in depth study made for the laboratory examination of some microorganisms, such Coliform sp., Escherichia Coli or Pseudomonas Aeruginosa, exactly for the premises where animals or industry are developing their activity.

Between 2 to 10 colonies/100ml Escherichia Coli presence found in Wiltshire pond and Avon Canal of these samples. Most of these water sources are considered freshwater even if large activity going on by or on their location, so the outcomes of the study are revealing potential risks and what kind of future steps can be taken to improve the quality of the water.

The contamination is spontaneously through the activity around the location, and cannot be considered as a continuous process, as the results of previous and further investigation found none or similar, but less colonies per sample.

Conclusions. The outcomes of this study were obtained through the Pseudomonas and pathogens presence into local pond and Avon Canal. 


\section{Introduction}

The research is based on taking raw water samples from different sources like lakes, ponds, rivers and tests them for microbiological key indicators like Coliforms sp., Escherichia coli and Pseudomonas aeruginosa. Local authorities are required to monitor Regulation 10 (Monitoring and risk assessment for water Conductivity, Enterococci, Escherichia coli, Turbidity etc.) supplies at least every five years, and more frequently if indicated by the risk assessment, the microbiological parameters.

The samples had to be collected multiple times from the same source as the examination of any single water sample is conclusive only at the time at when the sample is picked. Adequate outcomes from single test do not validate a supposition that the water is safe to be used for long period of time.

Contamination is frequently alternating and cannot be revealed by the analysis of a single sample. Drinking water must be safe for consumption and this is demarcated in law by specific principles for an extensive variety of constituents, microbiology and properties of water in the guidelines [26].

The standards are established to be shielding of public health and the significance of warranting that water quality is adequate to public consumption [6].

There is moral settlement between global scientific specialists, who define the health founded principles for drinking water, and the confirmation is acknowledged by the World Health Organization in the Guidelines for Drinking Water Quality. Other standards and specifications set in the EU by Drinking Water Directive and apply in all the member states of the European Union [23].

These are national standards and specifications in the regulations which apply only in the UK. In the UK all drinking water, whether from public supplies or other sources, has to meet standards laid down in the EU Drinking Water Directive (98/83/EC) [3].

The Drinking Water Inspectorate (DWI) was formed in 1990 to provide independent reassurance that public water supplies in England and Wales are safe and drinking water quality is acceptable to consumers. In the last years other UK regulation were realized to define better the internal laws regarding water for public consumption. In order to do that the laboratory assessments and procedures of testing water samples were carefully created and adjusted with law requirements [9]. Our research was conducted according within DWI regulations and testing methods.

\section{Materials and methods}

We used incubators and water bath capable of sustaining a temperature to within of $35^{\circ} \mathrm{C} \pm 2$; and $37{ }^{\circ} \mathrm{C}$ and to within $\pm 0.25^{\circ} \mathrm{C}$ of 44 and $44.5^{\circ} \mathrm{C}$. The temperature setting it is determined by the bacteria and the media of development. Other machinery: membrane filtrationapparatus with vacuum electrically activated pump and the suction flask. Membrane filters were used with $0.45 \mu \mathrm{m}$ porosity and of diameter fitting for absorbent pads.

In this research we collected sample within Lower Bristol Avon, Avoncliff weir (west of Bradford- on-Avon), Avonmouth Dock pier area, the Kennet and Avon Canal, Cotswolds, Frome River, Tellisford Gauging Station, North West Wiltshire ponds. Previously testing the samples were collected 500/1000 $\mathrm{ml}$ water into sterile water bottles. 
Description of samples

\begin{tabular}{|c|l|}
\hline Sample nr & \multicolumn{1}{|c|}{ Sample Source } \\
\hline 1 & Lower Bristol Avon \\
\hline 2 & Lower Bristol Avon \\
\hline 3 & Avoncliff weir (west of Bradford-on-Avon) \\
\hline 4 & Avoncliff weir (west of Bradford-on-Avon) \\
\hline 5 & Avonmouth Dock pier area \\
\hline 6 & Avonmouth Dock pier area \\
\hline 7 & the Kennet and Avon Canal, sample 1 \\
\hline 8 & the Kennet and Avon Canal, sample 2 \\
\hline 9 & the Kennet and Avon Canal, sample 3 \\
\hline 10 & the Kennet and Avon Canal, sample 4 \\
\hline 11 & Cotswolds location 1 \\
\hline 12 & Cotswolds location 2 \\
\hline 13 & Frome River sample 1 \\
\hline 14 & Frome River sample 2 \\
\hline 15 & Tellisford Gauging Station \\
\hline 16 & Tellisford Gauging Station \\
\hline 17 & North West Wiltshire ponds, sample 1 \\
\hline 18 & North West Wiltshire ponds, sample 2 \\
\hline 19 & North West Wiltshire ponds, sample 3 \\
\hline 20 & North West Wiltshire ponds, sample 4 \\
\hline & \\
\hline
\end{tabular}

The collected samples were processed within 2 hours or refrigerated within 2 hours at 2- $8{ }^{\circ} \mathrm{C}$ and processed within 24 hours. There were used $100 \mathrm{ml}$ samples for all the sources, so dilutions were not processed. All the samples were transported within controlled temperature, refrigerated containers $(2-5 \mathrm{C})$ and processed in the lab environment temperature $\left(18-20^{\circ} \mathrm{C}\right)$.

Pseudomonas aeruginosa being a Gram-negative, oxidase-positive bacteria which, in the setting of this technique, develops on selective media containing cetrimide $(\mathrm{C} 16 \mathrm{H} 33) \mathrm{N}(\mathrm{CH} 3) 3 \mathrm{Br})$, typically produce spiocyanin, under UV light (fluoresce), that hydrolyze the casein. The acid medium will inhibit the growth of bacteria other than Pseudomonas aeruginosa [17].

One way of classifying progressive risk values for faecal coliform or Escherichia coli is to consider 0 colony forming units $\mathrm{CFU} / 100 \mathrm{~mL}$ as fit in procedures of the World Health Organization, between 1-10 as a small risk; between 10-100 is medium risk; between 1001000 is a great risk and more than 1000 is very high risk [4].

Enumeration of Coliform (sp.) and Escherichia coli through a single membrane filtration technique by membrane lactose glucuronide agar (MLGA) incubated at $37^{\circ} \mathrm{C}$

In the setting of this method, the organisms that are oxidase negative, create acid from lactose or rapid $\beta$-gal, resulting any colour tone/dimension of yellow colonies on the membrane filter (subsequently incubation at $30^{\circ} \mathrm{C}$ for 4 hours tailed by an incubation at 37 ${ }^{\circ} \mathrm{C}$ for 14 hours) are considered as coliform bacteria [2].

The membrane filtration method is used to estimate bacterial populations in water that is low in turbidity. The presence of faecal coliform in drinking water or at freshwater sites is evidence that human or animal waste has been or is present [24]. 
This may be cause for concern because many diseases can be spread through faecal transmission. Also, coliform are principle indicators of water quality, pollution and effectiveness of the treatment processes. Procedure:

1. Measure $50 \mathrm{ml}$ of water into a filtration funnel.

2. Observe as a vacuum pulls the sample through a membrane filter.

3. Use tweezers to remove filter and place filter in a Petri dish containing media broth

Predominantly, suitable membrane filtration device and incubators and a number of utensils that will include:

Sterile sample bottles are used with proper volume, made from glass.

Machinery used are: incubators capable of retaining temperatures of $30.0 \pm 2.0^{\circ} \mathrm{C}$, $37.0 \pm 2.0^{\circ} \mathrm{C}$ and $44.0 \pm 0.5^{\circ} \mathrm{C}$; cycling incubators, fitted with timers, capable of achieving these temperatures.

Filtration device, disposable sterile filter funnels or filters funnels that can be sterilized and vacuum pump. Sterile gridded membrane filters were used, white, cellulose-created with $0.45 \mu \mathrm{m}$ pore size.

The volumes and dilutions of samples were chosen so that the counting of colonies on the MLGA membrane to be the best possible.

The time between the end of the filtration and the incubation phase was no longer than 2 hours, but preferably less than that.

The Petri dishes were overturned and positioned in the cycle incubator at $30{ }^{\circ} \mathrm{C}$ for $4.00 \pm 0.25$ hours and second stage at $37^{\circ} \mathrm{C}$ for a minimum of 14 hours. Tracking of the right temperature are made through the computer software linked directly to the incubators. After incubation period ended we observed the MLGA membrane filters under additional light source, using magnifying lens.

All yellow colonies were presumptive non- Escherichia coli, Coliform sp. bacteria and green colonies are Escherichia coli [22].

The total joined count of yellow and green colonies (and blue colonies are present) were regarded as the number of presumptive coliform bacteria. It was essential to note where pink colonies were existent in numbers that could affect the evolution of coliforms bacteria [7].

Expression of results. Counts for presumptive and confirmed Coliform sp. bacteria and Escherichia coli are expressed in colony forming unit per volume of sample. For drinking water the volume is typically $100 \mathrm{ml}$. Isolation and enumeration of Pseudomonas aeruginosa by membrane filtrationThe membrane filtration method was used to estimate Pseudomonas populations in water samples of this study.

Pseudomonas aeruginosa is environmental bacteria commonly found in soil and on plants. The organisms are capable to propagate in waters having decreased level of nutrients and should be absent in all drinking waters.

Pseudomonas aeruginosa are malleable pathogens, mainly in humans who have low level immune system. Important Figure s growing in untreated waters, swimming/spa pool water may, after soaking, yield ear infections or the follicular dermatitis. This microorganism importance as it is resistant to antibiotics [11].

We did the assessment of the incubated membrane filter after 24 hours and again after 48 hours for colonies of Pseudomonas aeruginosa demonstrating piocyanin production (green coloration).

The number of colonies at 24 hours may need to be noted as growth between 24 and 48 hours may be such that colonial growth results in the merging of colonies and the number of colonies at 48 hours may be less than the number of colonies at 24 hours. Colonies color may also be blue green, greenish brown/brown [23]. 
Also we examined the filter membrane below the UV lamp and add up all fluorescent colonies. These colonies, could be or not be pigmented, should also be measured as presumptive Pseudomonas aeruginosa.

Pseudomonas Agar Base is intended when the addition of the appropriate supplement (the medium becomes selective for Pseudomonas aeruginosa or Pseudomonas spp. generally.

The base medium is a modification in which magnesium chloride and potassium sulphate are present to increase pigment production.

Pseudomonas CN Supplement is recommended for the selective isolation of Pseudomonas aeruginosa (Incubated at $35^{\circ} \mathrm{C} \pm 2$ ). This media provided better recovery of Pseudomonas aeruginosa with boosted pigment development although intensely destroying Klebsiella, Proteus, Providencia spp., these being the upsetting contaminants of regular Pseudomonas C-N Selective Agar.

Colonial Appearance

Growing on $\mathrm{CN}$ or CFC medium is usually restricted to Pseudomonas sp. but other microorganism of the family Enterobacteriaceae could be present.

The incidence of bluish green or brown coloration or fluorescence can be considered as reasonable evidence of Pseudomonas spp., but confirmation tests must be carried out to confirm the identity of the organism.

Expression of results

Counts for presumptive and confirmed Coliform sp. bacteria and Escherichia coli are expressed in colony forming unit per volume of sample. For drinking water the volume is typically $100 \mathrm{ml}$.

The results were reported of Psudomonas aeruginosa colonies $/ 100 \mathrm{ml}$ of the neat sample (for $100 \mathrm{ml}$ water sample, the sum total on the membrane; for $10 \mathrm{ml}$ of sample, the amount on the membrane multiplied by 10 ; for $1 \mathrm{ml}$ of sample, the count on the membrane multiplied with 100).

\section{Results and discussion}

Determination of pathogen microorganisms are essential as daily simulations and situations with new sources of contamination near farms or were waste is dumped into freshwater sources. Water samples were enumerated from 1 to 20 (4 of each been taken from Wiltshire pond, Avon Canal, river and freshwater lake), and they been tested for all the indicators enumerated through membrane filter method.

Our results revealed that some of the sources analyzed contained pathogen microorganisms contaminations. Pseudomonas aeruginosa produced characteristic blue green or brown colored colonies when samples were kept at $37^{\circ} \mathrm{C}$ for up to 48 hours (indicative growth may exist after 18 hours).

The positive Pseudomonas locations were diverse, including lake, river, pond or canal, which may indicate contaminated untreated water. Chart 1 displays the incidence results. A total of 20 waters samples (rivers, canals, lakes, ponds) were collected from South West of UK (Somerset and North West Wiltshire) to be analyzed. A batch of 8 samples (10\%) were counted more than 10 colonies in $100 \mathrm{ml}$ for Pseudomonas aeruginosa, and $2<10$ colonies/100 ml; 10 samples were counted as zero colonies. Most of the positive samples with more than 10 colonies were processed from Kennet and Avon Canal and from local pond, nearby farming locations. 
Table 2

Pseudomonas aeruginosa sample results

CFU in $100 \mathrm{ml}$ for $P$. aeruginosa

Table 3

\begin{tabular}{|c|c|c|c|}
\hline \multicolumn{4}{|c|}{ P. aeruginosa } \\
\hline Pond & Lake & River & Canal \\
\hline 1 & 2 & 3 & 1 \\
\hline 8 & 2 & 3 & 5 \\
\hline 4 & 2 & 1 & 10 \\
\hline 0 & 2 & 4 & 5 \\
\hline 4 & 0 & 8 & 4 \\
\hline 1 & 1 & 3 & 2 \\
\hline 1 & 12 & 4 & 4 \\
\hline 2 & 2 & 2 & 5 \\
\hline 0 & 0 & 0 & 0 \\
\hline 10 & 2 & 4 & 2 \\
\hline 12 & 1 & 1 & 12 \\
\hline 1 & 3 & 2 & 13 \\
\hline 3 & 11 & 0 & 14 \\
\hline 7 & 1 & 8 & 6 \\
\hline 4 & 0 & 5 & 5 \\
\hline 2 & 3 & 10 & 10 \\
\hline 15 & 5 & 6 & 11 \\
\hline 0 & 6 & 4 & 4 \\
\hline 7 & 2 & 3 & 6 \\
\hline 2 & 0 & 2 & 8 \\
\hline & & & \\
\hline
\end{tabular}

\begin{tabular}{|l|c|c|}
\hline Results & $\begin{array}{c}\text { CFU in } \\
100 \mathrm{ml}\end{array}$ & $\begin{array}{c}\text { Number of } \\
\text { colonies/sample }\end{array}$ \\
\hline Pseudomon & $1-10$ & 2 \\
\cline { 2 - 3 } $\begin{array}{l}\text { as } \\
\text { aeruginosa }\end{array}$ & $>10$ & 8 \\
\cline { 2 - 3 } & 0 & 10 \\
\hline
\end{tabular}

Total Coliform sample results

Table 4

\begin{tabular}{|c|c|c|c|}
\hline \multicolumn{5}{|c|}{ Coliform sp } \\
\hline Pond & Lake & River & Canal \\
\hline 1 & 0 & 1 & 0 \\
\hline 0 & 0 & 0 & 2 \\
\hline 5 & 1 & 0 & 1 \\
\hline 0 & 0 & 0 & 0 \\
\hline 0 & 0 & 2 & 3 \\
\hline 1 & 0 & 1 & 0 \\
\hline 0 & 1 & 0 & 2 \\
\hline 2 & 1 & 0 & 2 \\
\hline 0 & 0 & 0 & 1 \\
\hline 1 & 0 & 1 & 3 \\
\hline 2 & 0 & 0 & 1 \\
\hline 1 & 0 & 1 & 0 \\
\hline 0 & 0 & 0 & 2 \\
\hline 0 & 1 & 1 & 7 \\
\hline 0 & 0 & 0 & 2 \\
\hline 2 & 1 & 2 & 1 \\
\hline 1 & 1 & 1 & 2 \\
\hline 0 & 0 & 0 & 0 \\
\hline 1 & 1 & 1 & 1 \\
\hline 0 & 0 & 1 & 0 \\
\hline & & & \\
\hline
\end{tabular}

Coliform positive samples were much more likely to come from an area were animals graze or farmers use slug, manure; another important source of contaminants could be the mooring boats on the canals.

All the results containing Coliform sp, from present research are displayed in the chart 2. As shown in the graphic, results of the experiment come positive for $48 \%$ samples and just 2 separate colonies were positive samples results for Escherichia Coli (1 was from North West Wiltshire small pond located in a grazing area and 1 from Avon Canal near Bristol).

Out of 80 total coliform samples collected during this study, $2.5 \%$ of the samples 
reached a total coliform count more than $5 \mathrm{CFU} / 100 \mathrm{ml}$, and $2.5 \%$ were Escherichia coli samples.

\section{Conclusions}

These results indicate that catchment area studied has a small probability of having a human health concern due to the fact the water taken from counties sources is treated and any detection of Coliform or Pseudomonas bacteria is not a pervasive issue, especially as the positive results for treated water are raised up with maximum professionalism.

The highest Coliform count was 7 colonies/100ml obtained in the samples from Canal may be an indication that the water sources are faecal contaminated.

This might be from local fauna or just boats contamination (due to improper dumping of waste, contamination of water by manure, private proper disposal of litter, is the reason for the microbial contamination of the fresh water and the suggestion that water borne diseases need for treatment and decontaminate the water to make it suitable for human consumption). According to the parameters given by the research presence of coliforms, pseudomonas in any water samples indicates that the water is highly polluted and is not water potable quality, because pathogens may origin various illnesses like cholera, which are highly damaging.

No drinking water sample should contain Coliform sp., Escherichia coli or Pseudomonas. Positive results of Coliform bacteria that are detected in the drinking water are immediately inspected. The suspected samples containing Faecal Coliform or Escherichia coli cannot be consumed without treatment (boiling for at least minute) [4].

Although total coliforms are not the best indicator of faecal contamination, they could signpost a greater risk for swimmers etc. developing skin eruptions or ear infections. For example, Pseudomonas aeruginosa is a probable human pathogen that is present on soil, plants etc. It roots a variety of contagious diseases, containing same skin rashes and external ear infections [26].

Some correlations between counts of P. aeruginosa and total coliform counts can be useful for future studies and future studies comparing bacteria from lakes, ponds, rivers and the results of the samples might be an important concern for human health. Future research will involve taking samples from more fresh water sources and mapping the area better, in order to recognize the highest count and possible contaminants sources. It is really important to determine if the highest coliform count is caused and linked with a high number of Escherichia coli counter, and if is related with animal or leakage infestation, and what is the casual risk and finally to diminish waterborne infections for this sources.

\section{References}

1. Code of Good Agricultural Practice for the Protection of Water (1998), London, Ministry of Agriculture, Fisheries and Food and Welsh Office Agriculture Department.

2. Sartory D.P. \& Howard L. (1992), A medium detecting ecglucuronidase for the simultaneous membrane filtration enumeration of Escherichia coli and coliforms from drinking water. Letters in Applied.

3. Dawson D. (2000), Water Quality for the Food Industry: Management and Microbiological Issues. Guideline No. 27, Campden and Chorleywood Food Research Association.

4. Edberg, S. C., Rice, E. W., Karlin, R. J. and Allen, M. J., (2000), Escherichia coli: the best 
biological drinking water indicator

5. Public health protection (2000), Journal of Applied Microbiology.

6. Geldreich, E. E., (1996), Microbial Quality of Water Supply in Distribution Systems, CRC Press Inc./Lewis Publishers.

7. Hijnen W. A. M., van Veenendaal, D. A., van der Speld, W. H. M., Visser, A., Hoogenboezem, W. and van der Kooij (2000), Enumeration of faecal indicator bacteria in large volumes using in site membrane filtration to assess water treatment efficiency

8. Industry Guide to Good Hygiene Practice: Vending and Dispensing Guide Supplement (To the Catering Guide) (2000), Automatic Vending Association, London, Chadwick House Group Ltd.

9. ISO 1990b Water Quality C Detection and Enumeration of Coliform Organisms (2016), Thermotolerant Coliform Organisms and Presumptive Escherichia coli.

10. Manual on Treatment for Small Water Supply Systems (2001), Drinking Water Inspectorate/WRc, Medmenham, WRc Ltd.

11. Mara, D., Cairncross A. (1989), Guidelines for the Safe Use of Wastewater and Excreta in Agriculture and Aquaculture, World Health Organization, Geneva.

12. Operational guidelines for the protection of drinking water supplies: safe guards in the operation and management of public water supplies in England and Wales (1988). London, Water Authorities' Association.

13. Standard methods for the examination of water and waste water, 19th edition (1995), Washington D.C., American Public Health Association.

14. Standing Committee of Analysts, The Microbiology of Drinking Water (2002), Part 2 Practices and procedures for sampling, Methods for the Examination of Waters and Associated Materials, Environment Agency.

15. Standing Committee of Analysts, The Microbiology of Drinking Water (2002), Part 6 Methods for the isolation and enumeration of Sulphite Reducing Clostridia and Clostridium perfringens by membrane filtration, Methods for the Examination of Waters and Associated Materials, Environment Agency.

16. Standing Committee of Analysts, The Microbiology of Drinking Water (2002), Part 9 Methods for the isolation and enumeration of Salmonella and Shigella by selective enrichment, membrane filtration and multiple tube most probable number techniques, Methods for the Examination of Waters and Associated Materials, Environment Agency.

17. Standing Committee of Analysts, The Microbiology of Drinking Water (2002), Part 8 Methods for the isolation and detection of Aeromonas and Pseudomonas aeruginosa by membrane filtration, Methods for the Examination of Waters and Associated Materials, Environment Agency.

18. Standing Committee of Analysts, The collection and processing of water and other environmental samples for the detection of legionella bacteria (2002), Methods for the Examination of Waters and Associated Materials, in this series, Environment Agency.

19. Principles of Water Supply Hygiene and Technical Guidance Notes (1998), London, Water UK.

20. Standing Committee of Analysts, The Microbiology of Drinking Water (2002), Part 7 The enumeration of Heterotrophic Bacteria by pour and spread plate techniques, Methods for the Examination of Waters and Associated Materials, Environment Agency.

21. Standing Committee of Analysts, The Microbiology of Drinking Water (2002), Part10 Methods for the isolation of Yersinia, Vibrio and Campylobacter by selective enrichment, Methods for the Examination of Waters and Associated Materials, Environment Agency.

22. Standing Committee of Analysts, The Microbiology of Drinking Water (2002), Part 5 Isolation and enumeration of Enterococci by membrane filtration, Methods for the Examination of Waters and Associated Materials, Environment Agency.

23. Standing Committee of Analysts, The Microbiology of Drinking Water - Part 1 (2002), 
Water Quality and Public Health. Methods for the Examination of Waters and Associated Materials.

24. Standing Committee of Analysts, The Microbiology of Drinking Water (2002) Part 3 Practices and Procedures for Laboratories. Methods for the Examination of Waters and Associated Materials, Environment Agency.

25. The Natural Mineral Water, Spring Water and Bottled Drinking Water Regulations (1999). Statutory Instrument 1999 No. 1540. Stationery Office Ltd.

26. The Private Water Supply Regulations (2002).

27. The Safe Sludge Matrix - Guidelines for the Application of Sewage Sludge to Agricultural Land (2001), Agricultural Development and Advisory Service.

28. The Water Supply (Water Quality) Regulations (2016), Statutory Instrument 2000 No.3184, Stationery Office Ltd.

29. Water Fittings and Materials Directory (2016), Water Regulations Advisory Scheme. 